\title{
MAPA VISUAL: A (DES)MONTAGEM COMO EXPERIMENTAÇÃO ANTROPOLÓGICA
}

\author{
Alexsânder Nakaóka Elias ${ }^{1}$
}

\section{Introdução:}

O presente artigo consiste em um substrato da minha tese de doutorado ${ }^{2}$ (finalizada em maio de 2018, na Unicamp), sendo fruto da pesquisa realizada junto à comunidade japonesa Honmon Butsuryu-shu (HBS), o primeiro grupo budista a se estabelecer no Brasil. Por meio das relações estabelecidas com os meus interlocutores, tive acesso às diversas práticas cerimoniais e rituais da HBS, atuando como um fotógrafo-antropólogo (Elias, 2018), isto é, alguém que compõe a sua etnografia a partir do ato de fotografar. Dessa forma, ao ocupar o lugar de um pesquisador que produzia (muitas) imagens fotográficas, percebi que o cerne da referida religião é a recitação de uma oração (Mantra) denominada Namumyouhourenguekyou, que também consiste em uma "Imagem Sagrada", como é referenciada pelos próprios "fiéis" (termo êmico).

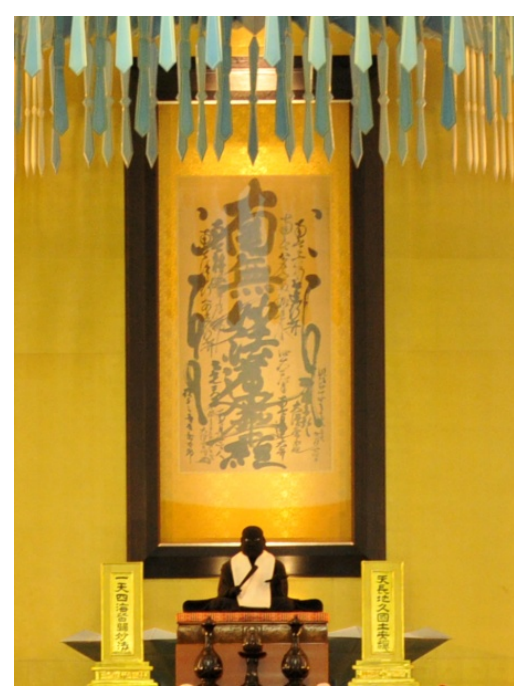

Imagem 01: Mantra e Imagem Sagrada, Namumyouhourenguekyou (foto do autor).

\footnotetext{
${ }^{1}$ Universidade Estadual de Campinas, Brasil. Email: alexdefabri@yahoo.com.br ORCID id : https://orcid.org/0000-0001-6746-0464

2 "Dupla imagem, duplo ritual: a Fotografia e o Sutra Lótus Primordial", desenvolvida com apoio inicial da Capes e, posteriormente, da Fapesp.
} 
A partir dessa "Imagem Sagrada" e de todos os sentidos que ela agregou à pesquisa, elaborei o que denominei de "Mapa visual", que constitui o segundo caderno de imagens da tese (Capítulo 05). Porém, é fundamental mencionar que este mapa foi produzido dentro de um conjunto de outras experimentações com as imagens e entre as imagens e os textos escritos que integraram o trabalho. Tais composições verbo-visuais tiveram a montagem como metodologia, em um sentido não hermético do termo, isto é, como algo capaz de colocar em movimento elementos heterogêneos, sejam eles as próprias fotografias; as imagens e a escrita; e as imagens e as narrativas orais realizadas pelos interlocutores, que posteriormente foram transcritas.

Assim, a confecção do mapa, - que se deu por meio de um amplo conjunto de fotografias (cerca de 10.000) -, é fruto de diversos e importantes processos de seleção que resultaram na escolha de 28 imagens, consistindo em uma montagem (na tese física/impressa) com a proporção de 15 páginas A4, que oferece ao leitor um "objeto" que pode ser manuseado, dobrado e desdobrado. Na tese digital, tal mapa é exibido em página dupla, ocupando, portanto, uma lâmina A3.

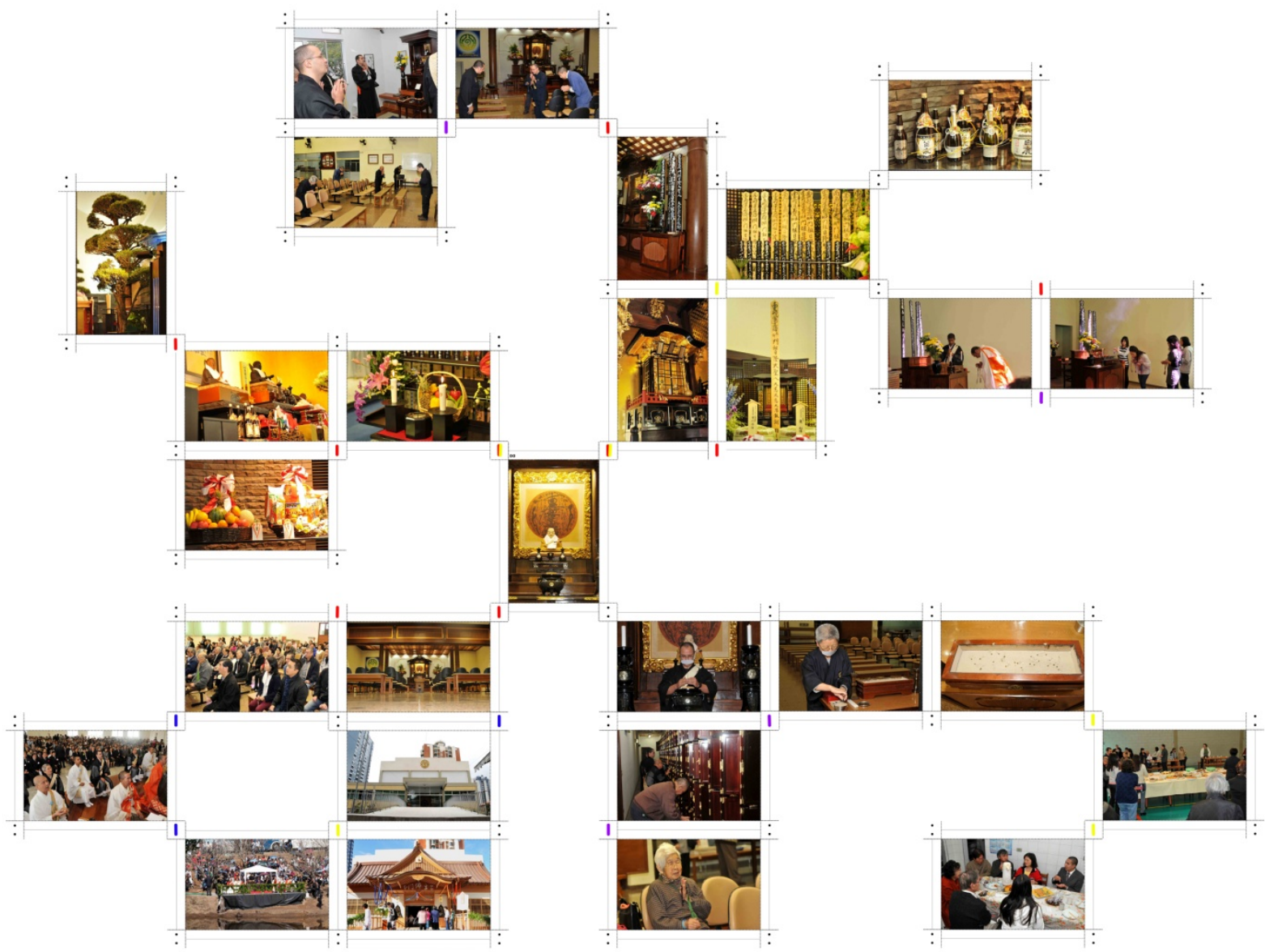

Imagem 02: Mapa visual (montagem com 28 fotografias do autor). 
No mapa, as associações são realizadas exclusivamente por meio de elementos visuais, sejam eles propriamente ligados à ontologia da imagem fotográfica (aspectos de iluminação, cor, saturação, contraste, elementos formais, etc.), a partir de componentes gráficos (na tese digital, traços coloridos que ligam uma fotografia à outra), linhas de costura (na tese física, os traços coloridos dão lugar aos fios tecidos com linhas de costura entrelaçadas, que unem tais imagens), dobraduras de origami, colagens e encaixes (tese física). Além disso, a intenção com essa grande montagem foi a de resgatar o acervo composto por 4.000 fotos coletadas durante o mestrado ${ }^{3}$ e associá-lo às 6.000 imagens produzidas durante o trabalho de campo no doutorado. Saliento, ainda, que nos Capítulos 06 e 07 da tese retomei as 80 fotografias ${ }^{4}$ inicialmente escolhidas para compor este experimento. Neste caso, elas foram mostradas ao leitorexplorador em preto e branco (P\&B), com o intuito de estabelecer um contraste embasado na presença (no caso do mapa) e na ausência de cores. Na ocasião, expus as imagens com um formato maior, já que no mapa elas aparecem impressas em tamanho reduzido $(10 \mathrm{~cm} \times 14 \mathrm{~cm})$.

\section{Metáforas visuais: o Namumyouhourenguekyou e as suas dobras:}

Lévi-Strauss (1989: 36-40) aproximou o modo de operar e pensar do artista ao pensamento mítico por meio de uma figura emblemática, que nomeou de "bricoleur". Este é alguém que inventa criativamente, sejam obras de arte ou as transformações dos mitos, de acordo com as suas apreensões dos elementos contidos no próprio repertório sobre o qual irá elaborar o seu pensamento, sempre colocando em tal projeto algo de si. Já James Clifford (2002) descreve um mecanismo semelhante, que chamou de "collage", um paradigma da racionalidade que é trazido à tona pelos trabalhos etnográficos.

Foi a partir da lendária figura do bricoleur que surgiu a ideia de apresentar as práticas cerimoniais e rituais da HBS com e por imagens montadas como um origami da flor de lótus. Tanto o origami ${ }^{5}$, arte japonesa tradicional de dobrar papel (do japonês

\footnotetext{
${ }^{3}$ A partir das (con)vivências que mantenho com a HBS do Brasil desde 2011.

${ }^{4}$ Inicialmente selecionei 80 fotografias, que foram distribuídas em três grandes mapas visuais. No final da tese, optei por apresentar apenas uma das composições.

${ }^{5} \mathrm{O}$ aspecto peculiar do origami é a utilização de um número restrito de dobras (sem cortes e/ou colagens) que combinadas formam desenhos complexos. Tradicionalmente, o origami é criado a partir de pedaços de papéis quadrados que, no entanto, podem originar objetos em três dimensões e com aspectos
} 
“oru”, “dobrar”, e "kami”, "papel”), capaz de criar re(a)presentações de seres e objetos (normalmente plantas e animais) com dobras geométricas (quadradas) de uma única peça de papel; quanto a flor de lótus (símbolo budista associado ao Buda Histórico ${ }^{6}$, à pureza e ao título do principal ensinamento da HBS) são elementos provenientes da cultura nipônica que, metaforicamente, ajudam a pensar por imagens.

Conforme já foi mencionado, compus durante as várias etapas de pesquisa de campo um extenso material visual, que ultrapassava 10.000 fotos. Ao ter em mãos esse conjunto, percebi a necessidade de organizar tamanho acervo e, para tanto, fiz uso da ideia/imagem da mesa de montagem de Aby Warburg (1929), que em um dos seus inovadores projetos (chamado Atlas Mnemosyne e realizado entre 1924 e 1929) reuniu aproximadamente 900 fotografias em um dispositivo de "painéis móveis", que constantemente eram montados, desmontados e remontados. Nessa obra, cíclica e inacabada, imagens heterogêneas (de tempos, origens e lugares distintos) dialogam entre si, formando e reformulando sentidos, ideias e sensações. A minha mesa de montagem parte do mesmo pressuposto, a saber, que imagens distintas podem se (co)relacionar, gerar um sentido e um pensamento por imagens e, depois, ao se reorganizarem, trazer à tona outras constatações e significações, sem esgotar o seu poder de combinação.

Com um conjunto reduzido de imagens, que "sobreviveram" às várias etapas de seleção (que não deixam de possuir, em maior ou menor grau, certa arbitrariedade), percebi que o rito de emanação da oração, doutrina e "Imagem Sagrada" Namumyouhourenguekyou (também chamada de Gohonzon), era o fundamento e sintetizava o essencial da religião HBS. Pois, em todos os momentos presenciados, que inicialmente foram divididos em temáticas na tese (cultos matinais, cultos póstumos, limpeza do altar, cerimônias matrimoniais e de batismo etc.), os sacerdotes buscavam expandir tal doutrina para o maior número de pessoas possível (sejam elas devotas ou leigas), por meio da pronúncia quase incessante desse Mantra.

Após delimitar o Namumyouhourenguekyou como o núcleo das práticas rituais da HBS, busquei uma forma imagética de demonstrar a existência dessas relações entre o Mantra Sagrado e o cotidiano religioso. Assim, inicialmente aflorou a imagem do sol

complexos, das mais variadas formas (circulares, retangulares, triangulares etc). Porém, o origami que é praticado desde o Período Edo (1603-1868) frequentemente foi menos rígido com essas convenções, permitindo até mesmo o corte do papel durante a criação do desenho ou o uso de outras formas que não a quadrada (retangular, circular, etc.).

${ }^{6}$ Segundo a tradição, o Buda Histórico (ou Buda Shakyamuni) era um príncipe hindu chamado Siddharta Gautama, que viveu há cerca de 500 anos antes de Cristo. Ele teria abandonado sua vida de riquezas para, posteriormente, estabelecer a base dos ensinamentos budistas (Sutras). 
(imagem 03), o próprio Namumyouhourenguekyou, com os seus raios luminosos que corresponderiam às variadas temáticas que inicialmente agrupei. Uma segunda imagem foi a de uma estrela (novamente o Sol) cercada por planetas, que orbitam ao seu redor atraídas por sua força gravitacional (os planetas seriam as temáticas e o Sol, a oração Namumyouhourenguekyou).

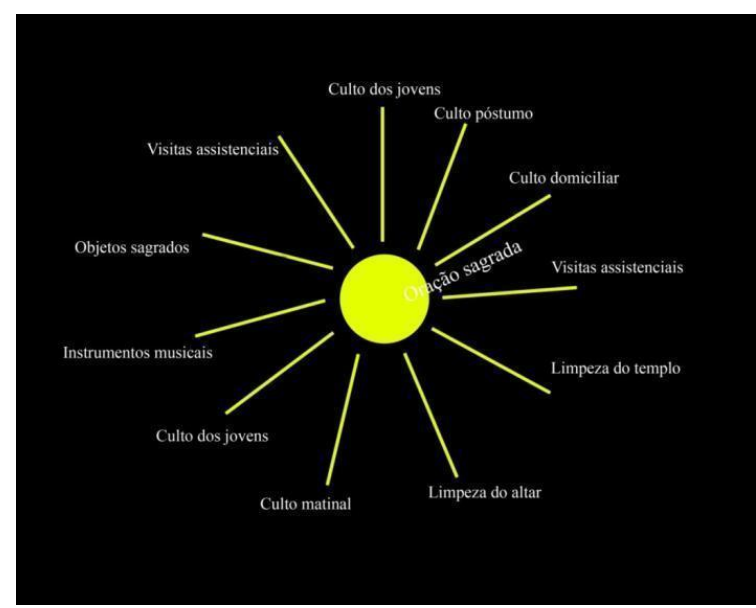

Imagem 03: Metáfora visual do Sol (montagem do autor).

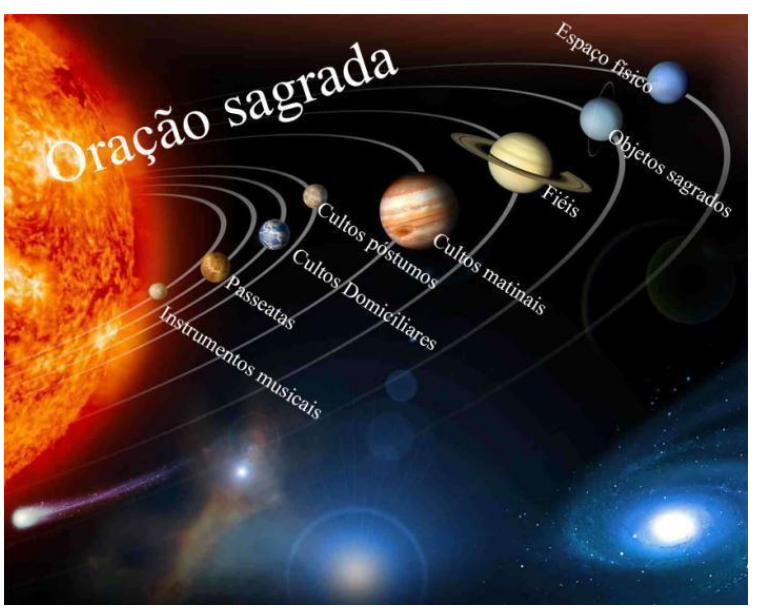

Imagem 04: Metáfora visual do sistema solar (montagem do autor).

A partir dessas metáforas (que não deixam de ser cartesianas), responsáveis por aguçar a minha imaginação, veio à tona outro elemento que melhor se conecta e se relaciona com o tema pesquisado. Ao tomar como parâmetro o sol/estrela, associei, não de maneira imediata, mas depois de imaginar e pensar por imagens, a figura da flor de lótus, um dos símbolos chave da religião budista ${ }^{7}$ e, também, o nome dado ao Sutra (ensinamento) considerado como primordial pela $\mathrm{HBS}^{8}$.

\footnotetext{
${ }^{7}$ Segundo o mito, no momento em que atingiu a Iluminação, o Buda Gautama segurava uma flor de lótus em uma das mãos.

${ }^{8}$ Sutra Lótus Primordial.
} 


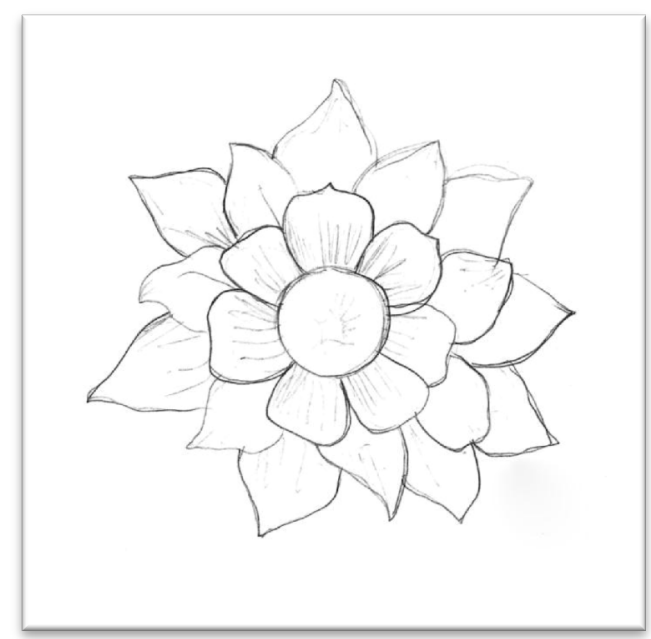

Imagem 05: Metáfora visual da flor de lótus (composição do autor).

Assim, a concepção para a experimentação deste caderno de imagens parte de tal metáfora visual, que surgiu após eu me deparar com uma flor de lótus feita de origami. Todas as partes dessa flor são compostas por retângulos com as mesmas dimensões, sejam elas as suas folhas ou pétalas. Além disso, a parte central não existe fisicamente/materialmente, não sendo formada por uma dobradura em si (por um pedaço de papel quadrado), mas composta pela união das pontas das pétalas e folhas que formam a flor. Tais pontos de intersecção das partes dobradas são amarrados por um pequeno arame dourado, que pode ser notado no centro do origami.

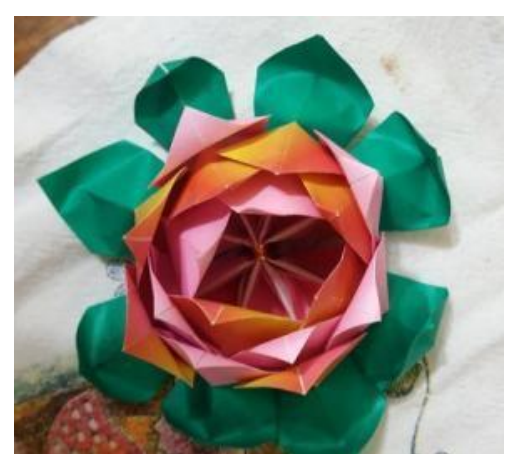

Imagem 06: Origami da flor de lótus (montagem e foto do autor).

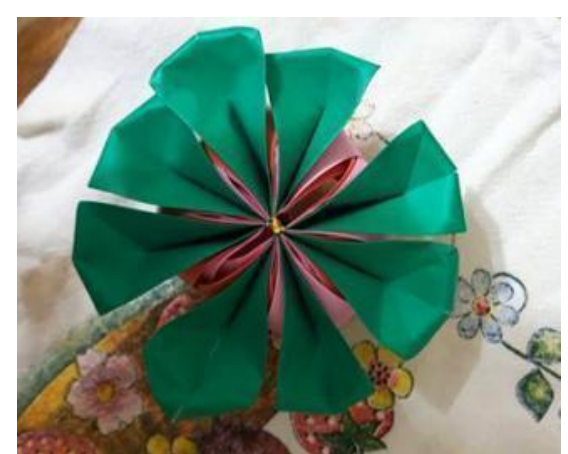

Imagem 07: Origami da flor de lótus (montagem e foto do autor).

A construção dessa metáfora fundamenta-se por distintos motivos, sendo necessário dizer que a questão das dobras é um tema capitular, abordado inclusive nas Artes Visuais, em geral, e na Fotografia, especificamente. Bruno (2009), por exemplo, 
utiliza o conceito do origami para mostrar que se faz necessário "abrir as imagens" e que a imagem "é algo sempre construído".

O que estas advertência e insistência poderiam significar para nós, ocidentais, que pretendemos trabalhar sobre conjuntos de imagens e várias montagens de imagens? A problemática é, efetivamente, complexa. E para torná-la mais concreta pensamos num exemplo preliminar, oriundo do mundo oriental: o célebre origami japonês. $\mathrm{O}$ "pássaro legendário japonês" [tsuru], "forma alada" ou "em pleno voo", oferecido a um amigo ou a uma amiga, torna-se um objeto simbólico que exige desdobramentos. A partir desta expressão da arte japonesa - chamada origami: [oro]: "dobrar" e [kami]: "papel", quantas questões poderíamos solicitar a uma simples "fotografia de vida", esse outro "pequeno pássaro que saiu", como gostamos de definir o ato fotográfico no momento da tomada? Trata-se, muitas vezes, da dimensão polissêmica da imagem - fotográfica em especial - para esconder, pensamos, nossa inércia, que a despreza com relação à primazia da escrita. Outras questões, no entanto, afloram: o que vem significar "desdobrar" uma imagem, "abrir uma imagem", na sociedade oriental? (Bruno, 2009: 93-94).

Assim, reflito sobre o presente experimento como uma composição de imagens heterogêneas (realizadas em tempos, espaços e contextos distintos, embora sobre o mesmo "objeto" de estudo) que dialogam e se encaixam de duas formas (e simultaneamente): de maneira simbólica, partindo de um eixo temático comum (a dos rituais da HBS) e, mais do que isso, por meio de relações e associações entre componentes visuais (cores, formas, linhas, traços, contraste, saturação, textura, gestos, ângulos, enquadramentos, etc.) presentes nas imagens; e literal, apoiado nas dobraduras, cortes, relação figura/fundo, dentro/fora e encaixes.

Em relação ao mapa, é importante retomar o modelo de pensamento apresentado por Warburg. Em seu "Atlas Mnemosyne", o historiador da arte "pretendia firmar sua procura de entendimento das culturas humanas, por meio de 79 painéis, de fundo preto, reunindo aproximadamente 900 imagens (principalmente fotografias em P\&B, retiradas de um arquivo de mais de 25 mil fotos)" (Samain, 2012: 52). Esse empreendimento nunca acabado conta, atualmente, com várias reedições, que trazem 66 pranchas ou painéis e é exemplar ao cumprir o desígnio de Warburg, a saber, "o de procurar ver como o Renascimento cristão dos séculos XV e XVI, na Europa - em especial o Renascimento Florentino -, tinha reinterpretado a Antiguidade pagã (ou, ainda, como a Antiguidade "sobreviveu” no Renascimento)" (Warburg, 2003, 2011).

Para tanto, Warburg nos mostra, como muito bem expressa Didi-Huberman, um dos seus principais exegetas, que existe um "após viver" (Nachleben) das imagens, "essa capacidade que as formas têm de nunca morrer totalmente e de ressurgir lá, 
quando menos se espera” (2002: 20). Ou, como afirma Klauss Berger, que ocorrem "ressurgências da antiguidade nas fases ulteriores das culturas" (apud Didi-Huberman, 2003: 97-103).

Tal composição do Atlas de imagens de Warburg buscava expor, portanto, “a gramática das 'Fórmulas [formas] de Pathos', essas famosas Pathosformeln"” (Samain, 2012: 53-54), na qual a questão dos gestos se fazia presente ${ }^{10}$. Para Samain, o Mnemosyne é, ainda, uma espécie de quebra-cabeça, teatro de sombras e de luzes sempre em construção, composto de formas, movimentos e "gestos expressivos de emoções profundas (Pathosformeln) do ser humano, ao longo dos séculos" (2012: 56). Junto ao conceito de "fórmulas do patético", que para Samain "tem tudo para apavorar os historiadores da arte e, mais ainda, os antropólogos", surge ainda a ideia de Nachleben, o “após-viver" das imagens (2012: 56-57). Na construção desses dois conceitos, fala-se, então, do após-viver das formas do patético ou dos gestos sobreviventes (ou "superviventes") ao longo da história da arte.

Cabe aqui dizer que, quando Warburg fala sobre a sobrevivência das formas (gestos) ao longo da história da arte, penso em uma relação possível com as formulações de Lévi-Strauss (1964, 1966, 1968, 1971), principalmente as que o autor realiza nas "Mitológicas", sobre o mitema. Para ele, o mitema seria a estrutura fundante e mínima dos mitos (assim como o fonema seria a unidade mínima de significação das linguagens), o que levanta uma origem comum (e estrutural) entre mitos de várias e distintas etnias. Dessa maneira, analogicamente reflito sobre a possibilidade da existência de um fotema, a partir das pranchas visuais elaboradas por Warburg e compostas por imagens fotográficas, nas quais as montagens levam em conta essa "estrutura" dos gestos e formas superviventes. Questiono-me se Warburg seria um estruturalista da arte, que buscava relacionar as formas e os gestos presentes nas imagens, ao longo do tempo.

Ao analisar, por exemplo, a prancha 41A de sua obra ("Expressão do sofrimento. Morte do sacerdote"), vemos a morte de Laocoonte, sacerdote de Apolo, filho de Acoetes e irmão de Anquises. O mito narra que, contra a vontade de Apolo, Laocoonte se casou e teve dois filhos, Antífantes e Timbreu. Quando Laocoonte estava

\footnotetext{
${ }^{9}$ As Pathosformeln são, com efeito, o medo, o terror, a coreografia da ninfa (isto é, a alma da mulher), o desejo, a paixão e a sedução; a vida, a felicidade, a esperança, a crença e a fé, o trabalho, o sofrimento, a morte e essa vontade de poder, sempre presente na humanidade (Samain, 2012: 56).

${ }^{10}$ Samain (2012: 57) mostra que Warburg entendeu a necessidade de uma antropologia histórica dos gestos que não seja prisioneira das "físiognomonias naturalistas ou positivistas do século XIX, mas capaz, ao contrário, de examinar a constituição técnica e simbólica dos gestos corporais numa dada cultura".
} 
fazendo um sacrifício a Netuno, Apolo enviou duas serpentes de Tênedos, que assassinaram o sacerdote e seus descendentes. Partindo dessa contextualização, é possível pensar especificamente nas imagens apresentadas por Warburg na referida prancha (imagem 08). Elas não constituem apenas simples cortes arbitrários no mundo, mas impressões, tramas visuais do tempo que se quis tocar e de tempos suplementares, anacrônicos e heterogêneos, constituindo-se, também, como uma "arte da memória"11.

Além disso, essa prancha aborda não somente obras de tempos heterogêneos (anos 1.470, 1.275, 1.435, 1.450, 1.495, 1.460, 1.540, 1.527, 1.895, 1.610, etc.), referentes diretamente ao mito de Laocoonte, mas, também, imagens relacionadas com dor, sofrimento, batalha e morte. Essas "imagens que ardem", mostram uma espécie de enfermidade, o que Didi-Huberman (2013: 390), ao seguir os passos de Walter Benjamin, chama de "mal-estar na cultura visual, uma poética capaz de incluir sua própria sintomatologia”. As pranchas de Warburg, a cada novo olhar, trazem novas significações e sentidos, elas "sobrevivem em um jogo de vai e vem, de sístole e diástole, de saltos e de repetições".

Essas associações totalmente abertas dão ao nosso olhar um aspecto de encruzilhada e nos estabelece em campo como arqueólogos das imagens ou como o "trapeiro" de Benjamin ${ }^{12}$. Dessa forma, somos convidados a (re)ordenar os traços de coisas superviventes (os "farrapos" do tempo), heterogêneas e anacrônicas, vindas de lugares e de tempos separados por lacunas que se mostram presentes na própria composição da prancha, pelos espaços "vazios", os respiros propiciados pelo fundo negro.

\footnotetext{
${ }^{11}$ Nessa prancha, Warburg reúne imagens do período do Renascimento Italiano e as mistura até mesmo com relatos textuais, como a página inicial das Epístolas canônicas septem (podemos pensar, aqui, que a escrita nos atinge através da visão/observação, sendo, também, uma imagem que nos é apresentada). Ele o faz por meio de relações que não seguem critérios arbitrários/ortodoxos. Utiliza, ao contrário, de um processo imaginativo, exatamente porque a imaginação possui uma potencial capacidade de realização e realismo, que a distingue da fantasia ou da mera frivolidade.

${ }^{12}$ Talvez esses vazios temporais, espaciais e até mesmo o que está fisicamente presente na prancha analisada, que gera interrupções momentâneas na imaginação e no pensamento, possam expressar o "suspenso" do qual falava Benjamin $(1987,2006)$, que é considerado primeiro como uma pausa, uma imobilização momentânea, a síncope em um movimento. Para o autor, a imobilização dos pensamentos é tão efetiva para o pensamento como sua mobilidade, originando a "imagem dialética".
} 


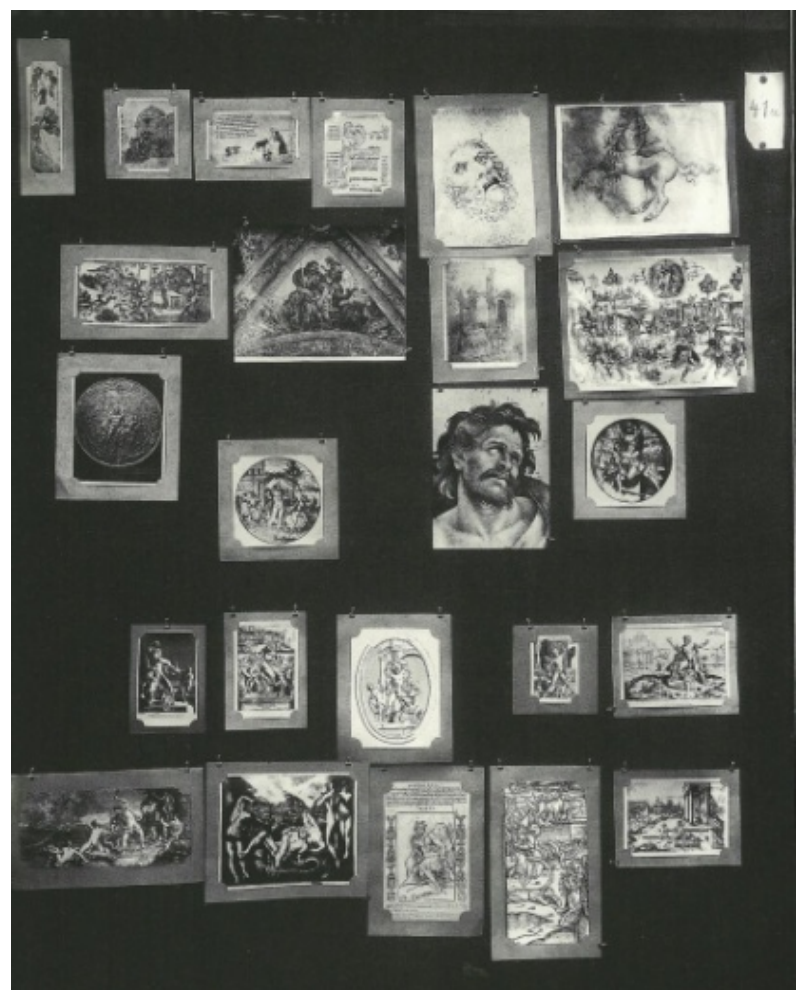

Imagem 08: Prancha visual 41a, do Atlas Mnemosyne (Warburg, 1929).

Nessa direção, Samain (2012: 78), afirma que a vida humana, e toda a cultura que a molda, é "um movimento ou, melhor dizendo, circuitos e espirais de movimentos que se entrelaçam, se entrecruzam e se procuram”. Ao pensar esses movimentos, é enfático ao dizer que "o tempo das formas e das imagens não pertence apenas ao tempo da história", fazendo, dessa forma, "parte de um tempo anacrônico" e aberto tanto ao passado quanto ao futuro, em contínuo estado de recomeço e recomposição. Dessa maneira, ao procurar "as estruturas que conectam os seres vivos" 13 , o autor afirma ainda que "toda imagem é uma memória de memórias, um grande jardim de arquivos declaradamente vivos". Mais do que isso, seguindo os passos de Didi-Huberman, diz que a imagem é uma "sobrevivência", uma "supervivência" e uma "forma que pensa":

A proposição é tanto mais ambígua e complexa que chega a insinuar - até sugerir que, independentemente de nós, as imagens seriam formas que, entre si, se comunicam e dialogam. Com outras palavras: independentemente de nós - autores ou espectadores - toda imagem, ao combinar nela um conjunto de dados sígnicos (trações, cores, movimentos, vazios, relevos e outras tantas pontuações sensíveis e sensoriais), ou ao associar-se com outra(s) imagem(ns), seria "uma forma que pensa" (Samain, 2012: 23).

\footnotetext{
${ }^{13}$ Segundo Samain (2012: 78), Warburg era "o homem que falava às borboletas" e que permaneceu o bom vizinho de Gregory Bateson, o homem que procurava as "estruturas que conectam os seres vivos". Ambos tornaram possíveis outro modo de pensar o mundo, outra arte de ser gente.
} 
Dessa forma, ao refletir sobre a "vida própria" e o "poder de ideação" e pensamento (Samain, 2012: 31) que as imagens nos trazem ao se associarem, é possível falar, junto à Samain, de "imagens cruzadas", numa analogia, não apenas terminológica, com o jogo "palavras-cruzadas". Neste sentido, busco associar o mapa visual também a este conceito. Portanto, o intuito com o experimento aqui exposto foi o de dispor as 28 imagens/origami escolhidas em um único (grande) painel, no qual a fotografia da Imagem Sagrada (Namumyouhourenguekyou) consiste no ponto nevrálgico e as outras 27 fotos saem, de forma ramificada, dali. Esse mapa possui $105 \mathrm{~cm}$ de comprimento $\mathrm{x}$ $89,1 \mathrm{~cm}$ de altura. Ao ser dobrado, ele forma um caderno de 15 páginas A4, na versão impressa. Já na tese digital, ele tem as dimensões de uma página A3 (a mesma dimensão de uma dupla página A4, com $42 \mathrm{~cm}$ de comprimento $x 29,7 \mathrm{~cm}$ de altura) ${ }^{14}$.

Ao considerar especificamente a versão impressa, o suporte dos mapas também se torna uma questão fundamental, ao constituir o que Hans Belting (2002) denominou como "meio". Para o autor, esse componente faz parte de uma relação triádica composta pelo nosso próprio corpo, local onde se formam as imagens mentais (que ele chama de “endógenas") e por onde são recebidas as imagens físicas ou "exógenas"; o meio (que, na tese digital, consiste no suporte bidimensional da tela) e a imagem (as figuras e aparições imagéticas, "exógenas”, como, por exemplo, as fotografias).

O "meio" é composto, assim, por papéis cartográficos, nos quais são coladas (com fita dupla face) as fotografias/origamis, que são encaixadas umas nas outras por meio de vincos e dobraduras. De fato, o intuito é que o leitor-explorador também perceba o "fundo" sobre o qual estão as fotografias, que normalmente seria esquecido. O convido, dessa maneira, a retomar e olhar com cuidado o próprio suporte, que normalmente é matéria de pouca luz, mas que também é algo que sobrevive ou supervive nas imagens.

Em relação à montagem física dos mapas, aliás, é instigante refletir sobre o próprio processo de confecção, nos quais pés, mãos e corpo atuaram. Ingold (2015: 101104) fala, no Capítulo 4 do livro "Estar vivo""15, sobre a experiência de confeccionar

\footnotetext{
${ }^{14}$ Nesta versão, é ofertada ao leitor-explorador a possibilidade de ampliar o tamanho das imagens por meio do zoom, sem que haja perda de qualidade. Assim, ele poderá atentar-se aos detalhes da montagem, já que as fotos expostas estarão em alta resolução. Neste sentido, embora Ingold ${ }^{14}$ (2012) talvez discorde, penso na versão digital do mapa imagético também como uma "coisa", que possui uma superfície que propõe ao leitor que se relacione com ela, mesmo que de maneira distinta da forma com a qual interage com o material impresso.

15 “Andando na prancha: meditações sobre um processo de habilidade” (Ingold, 2015: 95-110).
} 
uma estante com pranchas de madeira. Assim, o autor ressalta as etapas desse processo, que incluem a preparação dos materiais (com a escolha da serra e das ferramentas corretas) e o início do trabalho, que envolve uma "sinergia entre profissional, ferramenta e material".

No meu caso, a montagem do mapa (o objeto "físico", ou a "coisa", de que nos fala Ingold) se deu após a confecção e impressão do restante da tese, constituindo-se como um trabalho artesanal. Nesse ofício, tive de utilizar materiais como estiletes, tesouras, fitas dupla-face, linhas coloridas, réguas, compassos, trenas, lápis para realizar marcações, papéis de certo tipo (e qualidade) para o fundo e outros para as folhas nas quais estão impressas as próprias fotos. Este trabalho me faz refletir, dessa forma, na questão dos materiais e da materialidade, no fazer manual e, também, no "pedal", visto que tive que dispor esses componentes em uma grande mesa, devido às proporções dos mapas ${ }^{16}$. Nessa direção, era necessário caminhar ao redor da bancada para montar, aos poucos, cada uma das versões dos mapas imagéticos, que ainda seriam (re)dobrados para ficarem com as proporções do A4, necessidade imposta pelo tamanho padrão das teses acadêmicas ${ }^{17}$.

Em última análise, ressalto que mesmo com a utilização de instrumentos de medição precisos como a régua, o compasso e a trena, os mapas visuais de cada unidade da tese nunca ficaram exatamente iguais, pois foram feitos individualmente, em um processo demorado. As suas proporções, tanto em relação ao fundo (que chamei de suporte ou "meio"), quanto em relação à composição e disposição das fotografias, são únicas $^{18}$, talvez por uma inabilidade técnica de quem os compôs.

\section{Dobraduras:}

Em relação à ligação das imagens, a dobra é o elemento fundamental, ao seguir o conceito do origami. Porém, para que tais junções se realizassem fisicamente, foi necessário literalmente cortar a imagem e produzir vincos, rasgaduras e encaixes,

\footnotetext{
${ }^{16}$ Tim Ingold (2015), especialmente nos capítulos 2 ("Materiais contra materialidade"), 3 ("A cultura no chão: o mundo percebido através dos pés") e 4 ("Andando na prancha: meditações sobre um processo de habilidade") do livro "Estar vivo", me faz pensar nas questões gestuais e corpóreas com as quais me deparei ao longo do processo de confecção dos mapas visuais.

${ }^{17}$ Durante a composição dos mapas que foram apresentados no Exame de Qualificação (maio de 2017), eu estava com o tornozelo esquerdo fraturado, o que dificultou muito o meu caminhar ao redor da mesa e, consequentemente, na confecção dos mesmos. Contudo, a contusão fez com que eu me atentasse para a importância sensorial durante a elaboração do experimento, isto é, me fez lembrar que possuía pés.

18 Penso, neste caso, no conceito de aura e de obra de arte, proposto por Walter Benjamin (1936) em "A obra de arte na era da sua reprodutibilidade técnica".
} 
levando em conta os conceitos de montagem não apenas metaforicamente, neste caso. Além desses cortes, as imagens também foram furadas em seus pontos de intersecção, ou, quando não o foram, receberam marcações que indicam o local dessas incisões. Disponho, assim, uma possibilidade virtual, caso seja solicitada pelo leitor-explorador, de ele mesmo sulcar as imagens e reposicioná-las de maneiras distintas das que eu sugeri.

Os locais dos furos são indicados por dois pontos na cor preta e servem, ainda, para passar o "fio que liga" (literalmente, uma linha de costura grossa, passada por uma agulha), que, por meio de um nó metafórico e físico, une imagens heterogêneas. Essas fotografias dialogam entre si não por aspectos meramente temáticos e classificatórios (como, por exemplo, “altares", “culto póstumo", “passeata”, “catequese” etc.), mas por características visuais relacionadas à cor, tonalidade, saturação, formas, textura, composição, ângulos, gestos, poses etc. Por fim, é necessário dizer que as tonalidades de tais linhas não foram escolhidas totalmente ao acaso, mas possuem uma ligação (simbólica) com o Budismo, pois são as cores da religião ${ }^{19}$, estando presentes na bandeira e nas indumentárias dos sacerdotes da HBS.

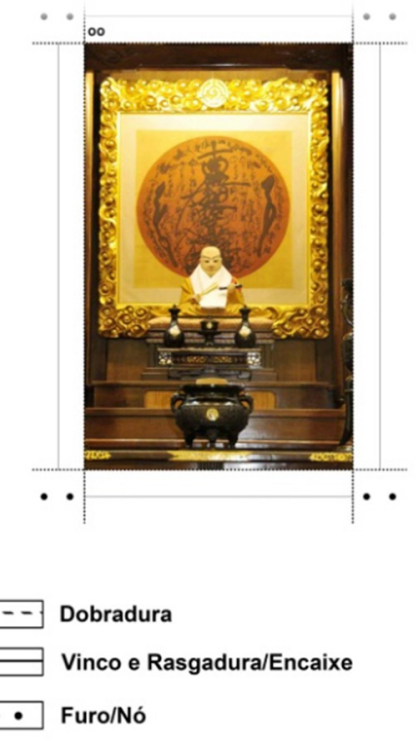

Imagem 09: Fotografia central do mapa visual (foto e montagem do autor).

\footnotetext{
${ }^{19}$ Azul (que significa paz, bondade e compaixão), amarelo (que representa um preceito capitular do Budismo, o "caminho do meio", entre os extremos), vermelho (representa as bênçãos da prática budista), branco (representa a pureza do dharma, dos ensinamentos do Buda) e laranja (representa a sabedoria).
} 


\section{Jogo de cartas fotográficas, imagens cruzadas e tabuleiro de xadrez:}

Em um sentido inverso (no sentido de um "duplo" e não de algo em oposição), de desconstrução, de desdobra e de desmontagem, é possível pensar no mapa visual como um jogo de cartas fotográficas e um tabuleiro de xadrez. Essas metáforas revelam, um tanto imaginativamente, as múltiplas posições e os movimentos imagéticos de um conjunto heterogêneo de fotos, que poderão (sempre) ser rearticuladas e repensadas.

Frequentemente, nos encontramos portanto diante de um imenso e rizomático arquivo de imagens heterogêneas difícil de dominar, de organizar e de entender, precisamente porque seu labirinto é feito de intervalos e lacunas tanto como de coisas observáveis [...] Tentar fazer uma arqueologia sempre é arriscar-se a por, uns junto a outros, traços de coisas sobreviventes, necessariamente heterogêneas e anacrônicas, posto que vêm de lugares separados e de tempos desunidos por lacunas. Esse risco tem por nome imaginação e montagem [...] A montagem será precisamente uma das respostas fundamentais a esse problema de construção da historicidade. Porque não está orientada simplesmente, a montagem escapa às teleologias, torna visíveis as sobrevivências, os anacronismos, os encontros de temporalidades contraditórias que afetam cada objeto, cada acontecimento, cada pessoa, cada gesto. Então, o historiador renuncia a contar "uma história" mas, ao fazê-lo, consegue mostrar que a história não é senão todas as complexidades do tempo, todos os estratos da arqueologia, todos os pontilhados do destino (Didi-Huberman, 2012: 06-07)

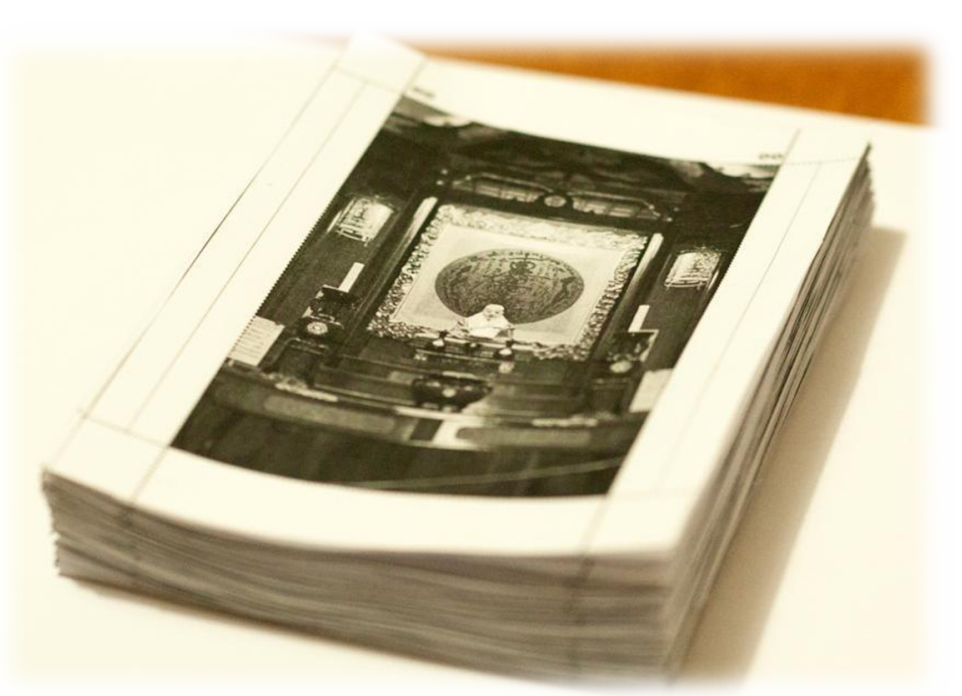

Imagem 10: Baralho de imagens fotográficas (fotos e composição do autor). 


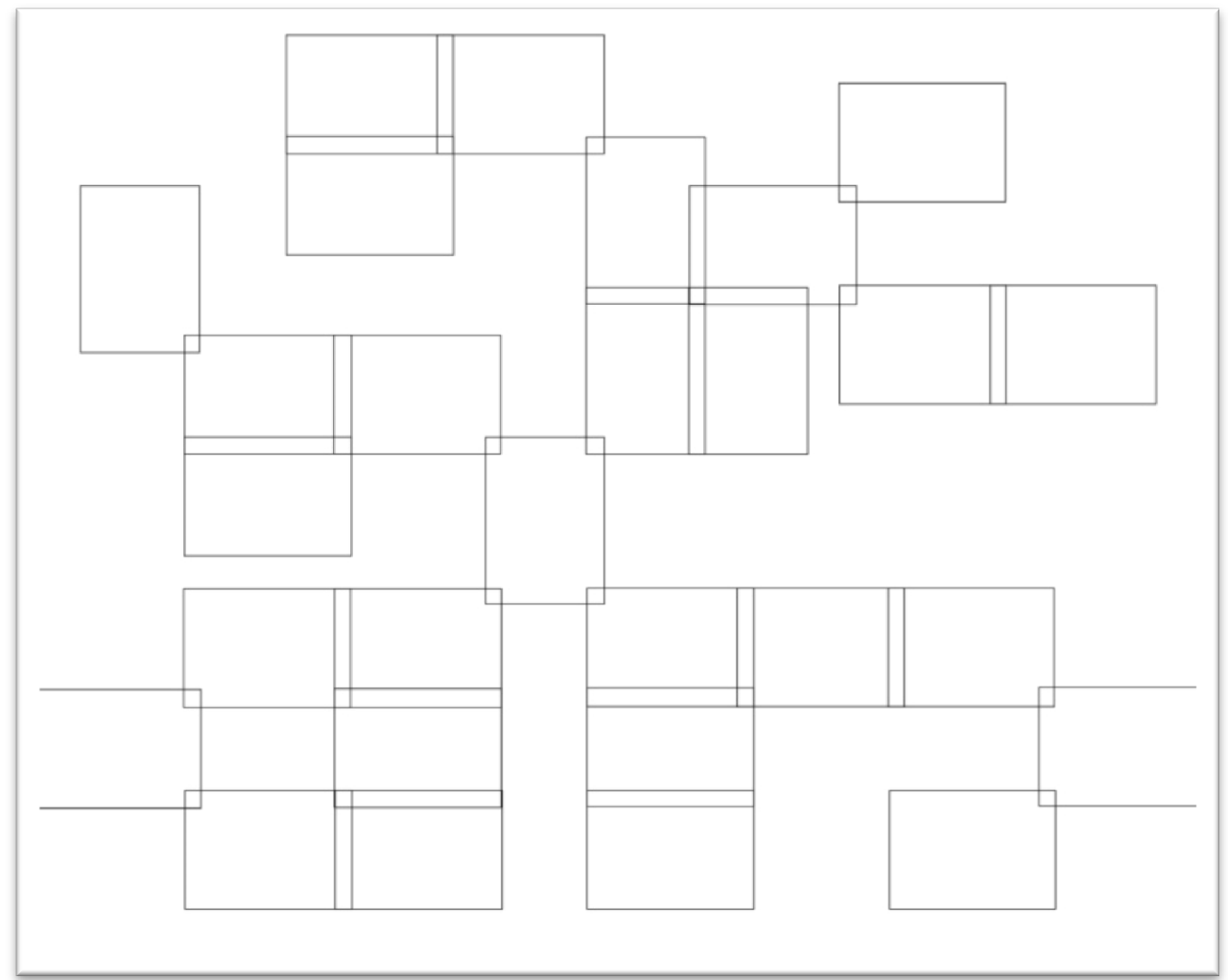

Imagem 11: Imagens cruzadas e tabuleiro de xadrez (composição do autor).

Portanto, embora tenha estabelecido este grande conjunto visual a partir e de acordo com a minha "leitura" dos rituais, cerimônias e relações da HBS, essa composição está distante de esgotar as possibilidades de relacionar as imagens. Consiste, de fato, em um empenho para pensar por e entre imagens de forma imaginativa, mas também analítica. Neste sentido, ao considerar a constelação apresentada, existem particularidades que devem, em um último esforço conceitual, serem explicitadas.

A primeira questão diz respeito ao sentido de leitura, ou melhor dizendo, de exploração visual das imagens. Pretendo enfatizar que tanto os cenários rituais por mim presenciados no convívio com a comunidade HBS, quanto a sua apresentação a partir da montagem fotográfica (mapa), se dispõem de forma circular. Para isso, sugiro que a partir de um centro (não necessariamente localizado no meio do painel, mas de onde emanam todas as outras fotografias), que consiste na Imagem Sagrada Namumyouhourenguekyou, saem de forma ramificada, como raios (solares, mas também os raios da matemática, que consistem na metade do diâmetro de um círculo), as outras imagens.

Aqui, talvez seja possível pensar em uma "malha visual", algo próximo ao “meshwork" de Ingold (2013: 131). O autor afirma que existe uma diferença entre ler e 
ver (ou perceber), capaz de gerar um conflito entre legibilidade e visibilidade, tendo, de um lado "pura visualidade e, de outro, um sistema de signos legíveis". A partir desse pensamento, diferencia "meshwork", uma malha que possui "nós", pontos onde linhas coincidem e se amarram, - estes constituídos nos mapas pelos pontos de intersecção marcados pelos "nós" com linha colorida, que relacionam questões como cor, iluminação, gestos, textura e outros elementos visuais -, de "network" ${ }^{20}$, uma rede que possui "nódulos".

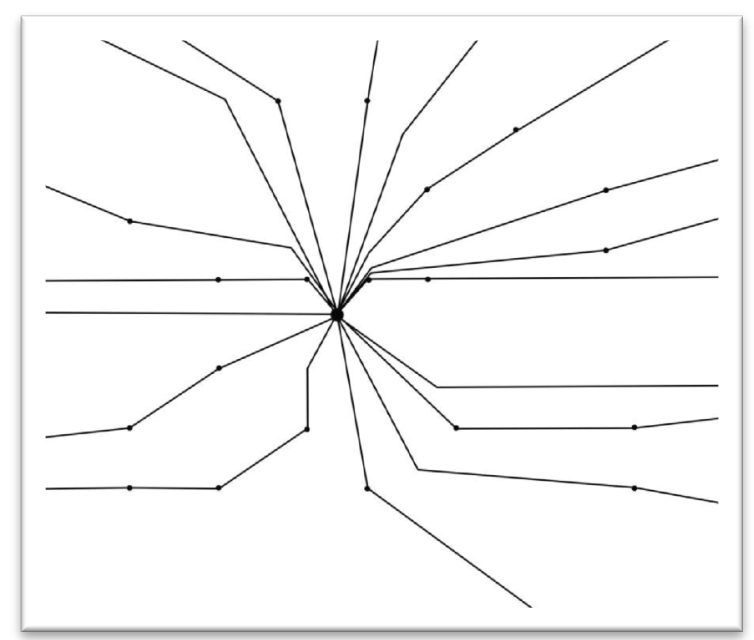

Imagem 12: Sentido de leitura "Network" (composição do autor

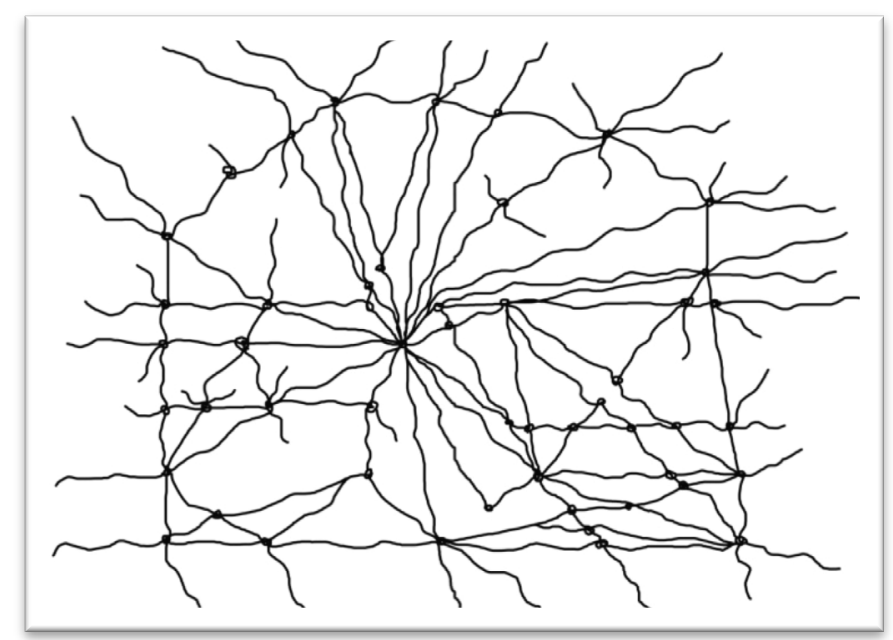

Imagem 13: Sentido de leitura "Meshwork" (composição do autor).

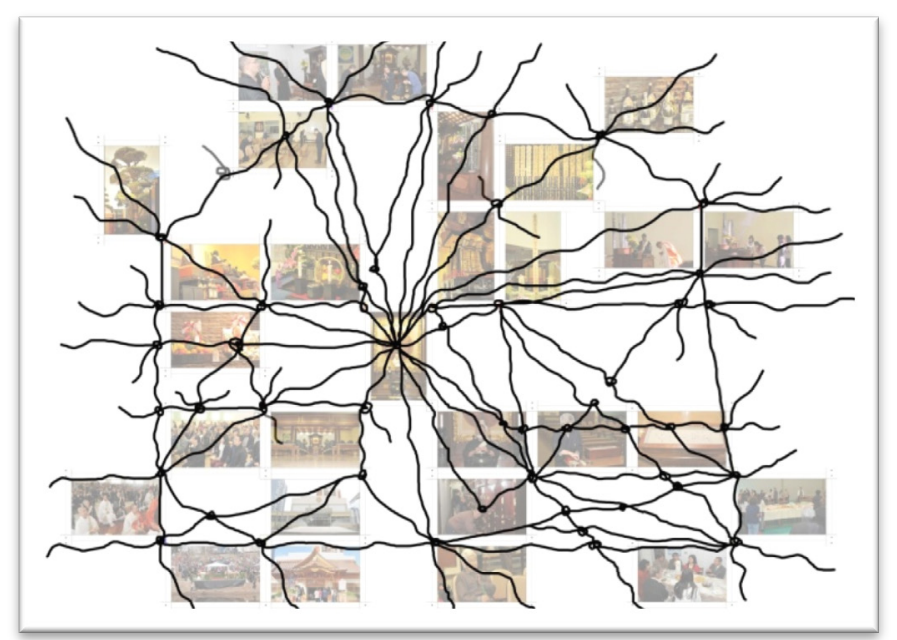

Imagem 14: "Meshwork" sobreposto ao mapa visual (montagem do autor).

\footnotetext{
${ }^{20}$ Aqui, a referência principal é o conceito de ANT (Actor Network Theory ou, em português, "Teoria ator-rede"), desenvolvido por Bruno Latour (2005) que, ao analisar a atividade científica, leva em consideração tanto os atores humanos como os não humanos, estabelecendo o que chama de elementos "híbridos".
} 
Também é necessário demonstrar, em última análise, outros caminhos possíveis de exploração existentes no conjunto de imagens do mapa, como as horizontais e as verticais. É plausível, assim, imaginar uma visualização tanto horizontal e da esquerda para a direita, que prioriza uma leitura "ocidentalizada" das fotografias; quanto na vertical e da direita para a esquerda, semelhante ao sentido de leitura dos países do oriente, como o Japão, no qual a escrita e a leitura do kanji/ideograma é iniciada da direita para a esquerda e de cima para baixo.

Imagem 15: Visualização horizontal-01 (composição do autor).
Imagem 16: Visualização horizontal-02 (composição do autor).

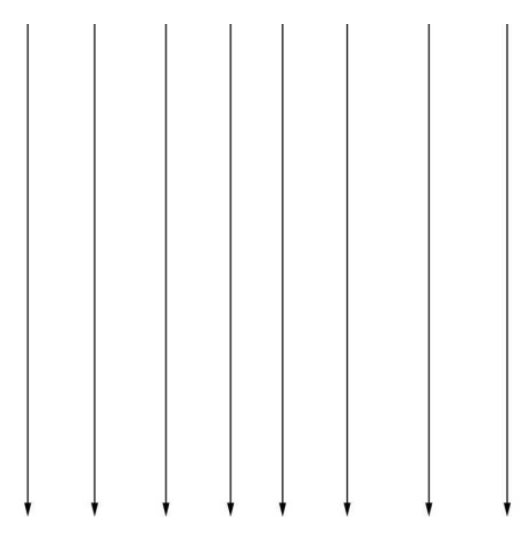

Imagem 17: Visualização vertical-01 (composição do autor).

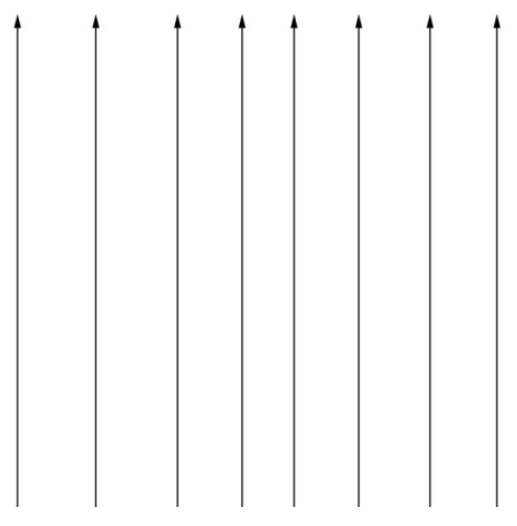

Imagem 18: Visualização vertical-02 (composição do autor). 


\section{Por uma exploração circular:}

Ao partir de uma fotografia tomada como central, que consiste no Gohonzon localizado na Catedral Nikkyoji (São Paulo, SP), o intuito inicial foi estabelecer um sentido circular de visualização do mapa, como se dessa imagem nuclear saíssem diversos raios, no sentido formal e geométrico do termo (que significa metade do diâmetro de uma circunferência, ou seja: $d=2$ r). De fato, pensar a montagem das imagens de forma circular levanta uma questão instigante, que tensiona o sentido de visualização da escrita greco-romana (horizontal, da esquerda para a direita) e até mesmo da escrita japonesa (ideogramas verticais, lidos da direita para a esquerda).

Além disso, esse sentido de leitura-exploração possui diversas potencialidades reflexivas. Bruno (2009) fala sobre o "arranjo visual circular" de imagens fotográficas, sublinhando que:

O círculo apresenta as fotografias não somente referenciando-as à forma de um tempo que passa - o tempo e o movimento da agulha de um relógio -, e mais profundamente, às alavancas de tempo que compõem a história de uma vida, de toda vida. Essa disposição circular nos permite explorar ainda as conexões, correspondências e aproximações entre as fotografias, que antes apareciam distanciadas ou no mínimo impensadas [...] Não impondo-nos um sentido de leitura horário ou anti-horário, a forma circular nos oferece múltiplas interpretações, em função das infinitas associações possíveis entre imagens, a partir de traçados diagonais, lineares, transversais, perpendiculares e também circulares (Bruno, 2009: 36).

Dessa forma, realizei na tese a exegese do mapa a partir dessa ordenação circular. Para tanto, criei um grande percurso de exploração com as 28 fotografias, mas também cinco caminhos menores para facilitar a compreensão das descrições, ressaltando novamente que tal análise permite outros inúmeros sentidos de visualização, “diagonais, lineares, transversais e perpendiculares" (Bruno, 2009), trajetos rizomáticos e fluidos. Algumas dessas rotas alternativas, inclusive, que aparecem em destaque no mapa impresso por meio de fios coloridos (aqui representados por traços gráficos), estão nos "roteiros visuais" elaborados para a exploração de cada parte do mapa. Os trajetos de exploração referidos são os seguintes: 

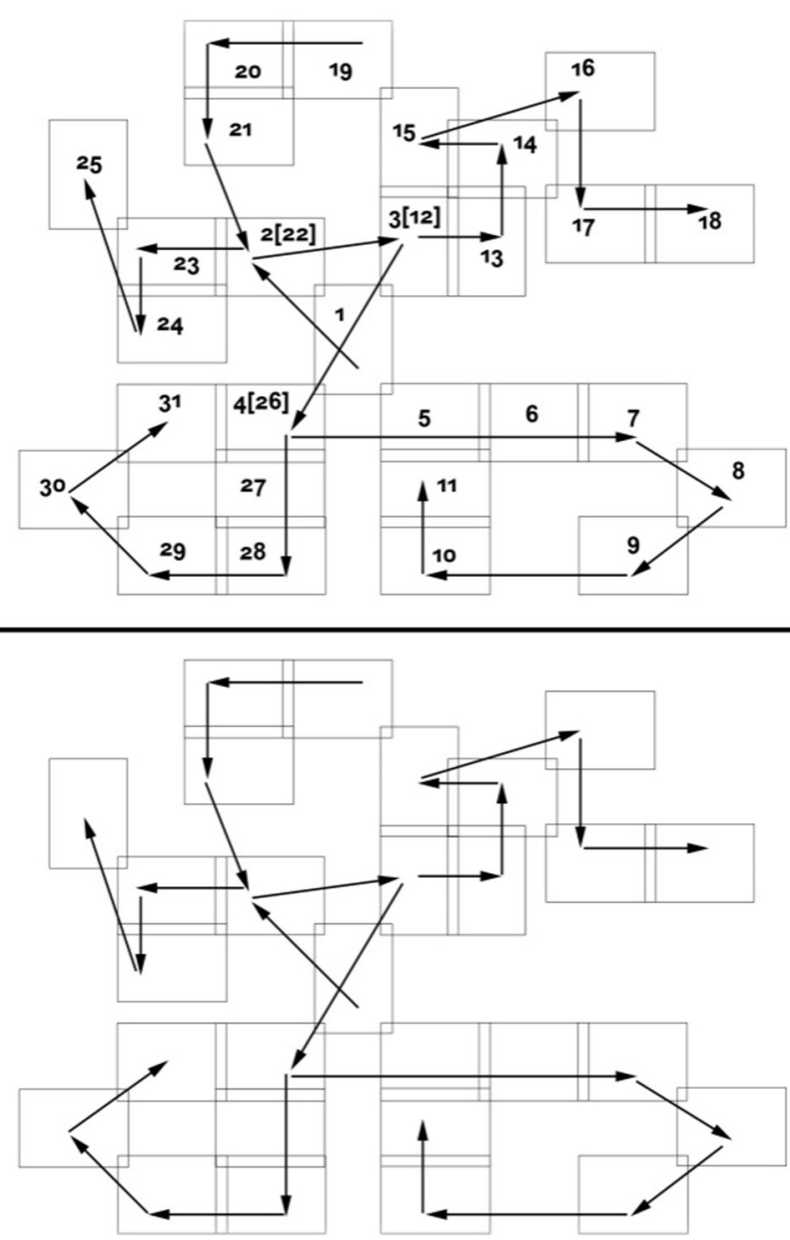

Imagem 19: Percursos de exploração visual (montagem do autor).

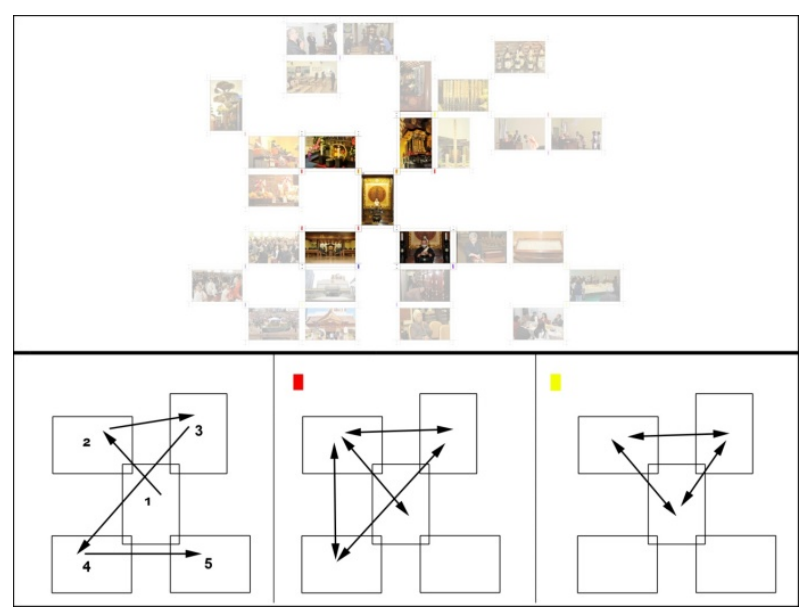

Imagem 20: Percurso 01 (montagem do autor).

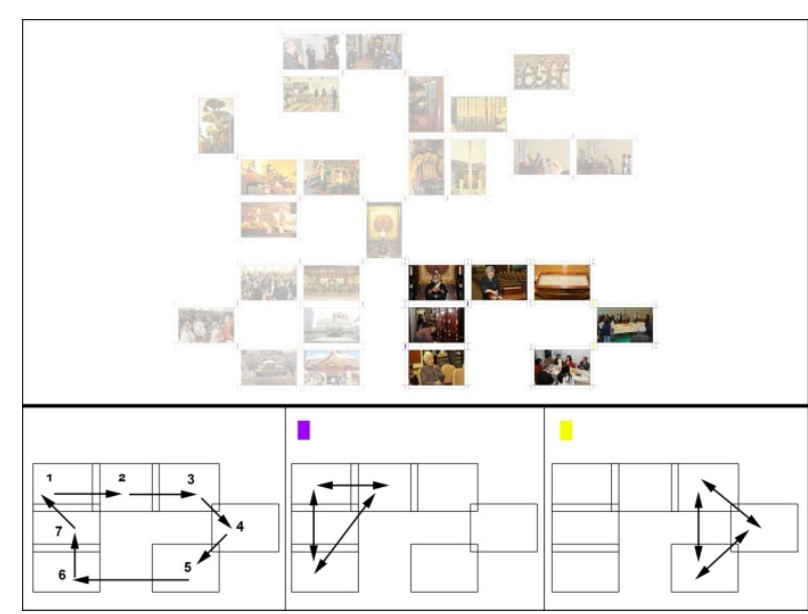

Imagem 21: Percurso 02 (montagem do autor). 


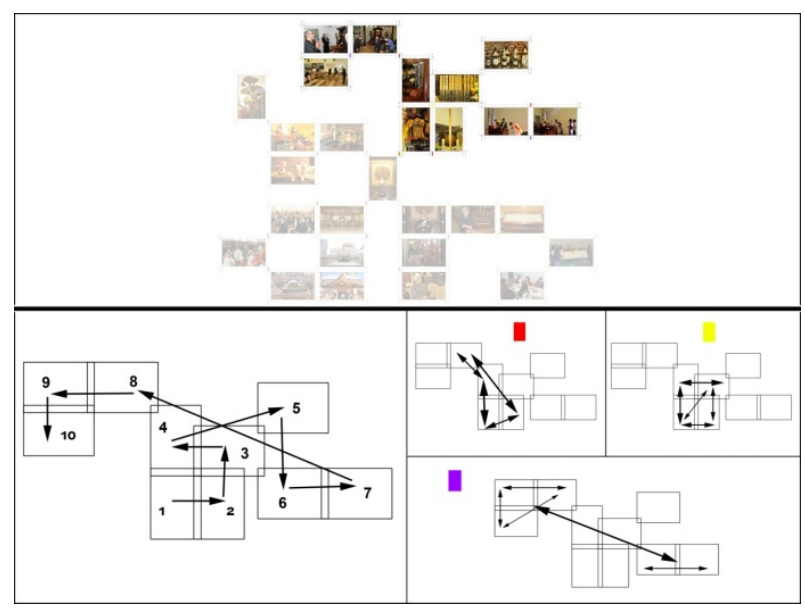

Imagem 22: Percurso 03 (montagem do autor).

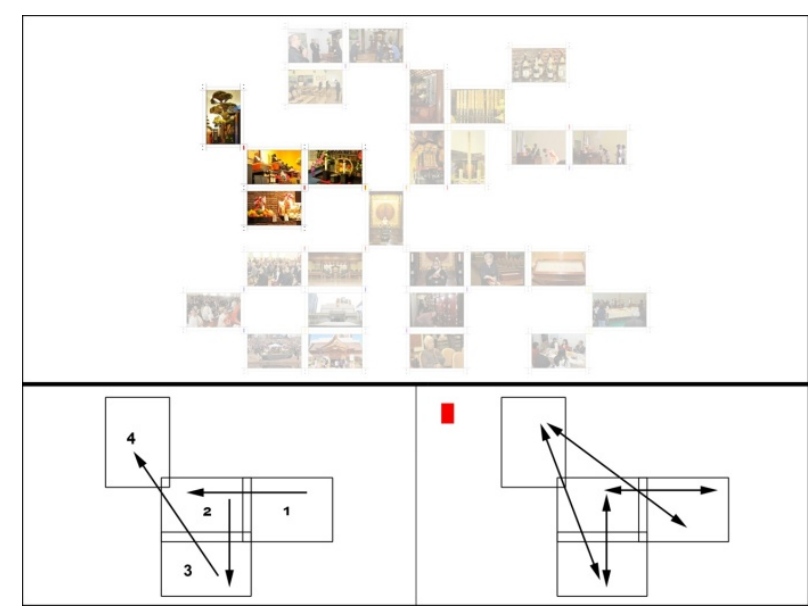

Imagem 23: Percurso 04 (montagem do autor).

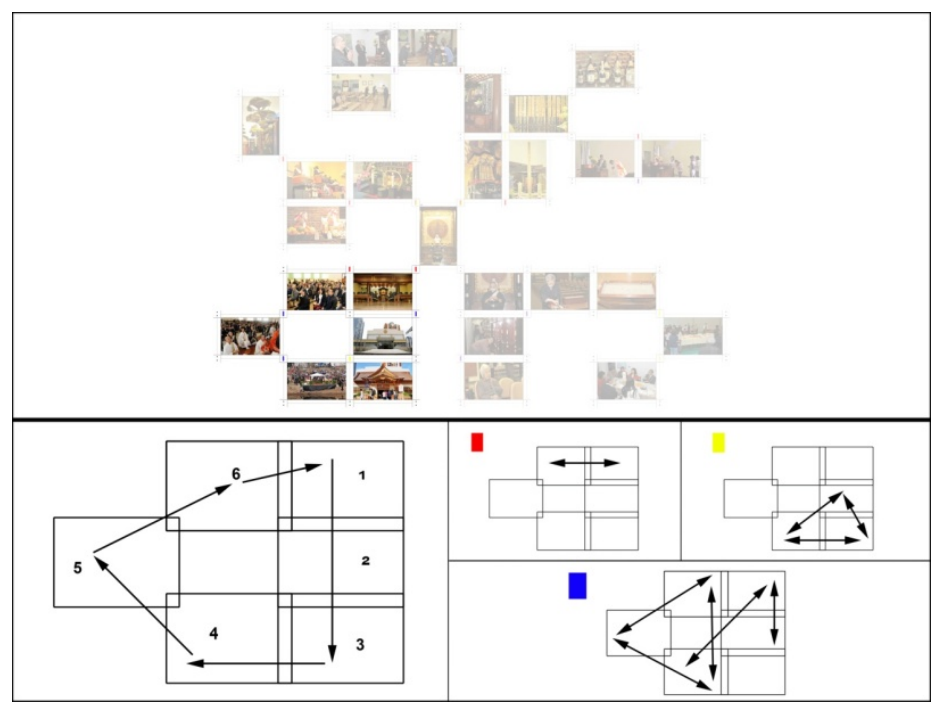

Imagem 24: Percurso 05 (montagem do autor).

\section{Desfecho ou Exegeses visuais: Rotas principais e outros caminhos possíveis:}

Como construção baseada na dialética, a montagem gera reflexividade sobre as imagens, o que nos reenvia ao modo de pensar por imagens como uma forma de produção de conhecimento. Neste sentido, a capacidade narrativa da montagem tem papel crucial na construção da imagem como experiência, uma vez que a montagem produz choques de imagens, criando contextos de conversação, conexões que estabelecem novas relações e novos sentidos. Reside, aqui, o encontro definitivo entre etnografia e imagem mediado pela experiência (Gonçalves, 2016: 22).

O mapa visual, apresentado como capítulo 05 e que abre a terceira parte da tese (intitulada "Dupla-imagem, duplo ritual"), possui o intuito de oferecer ao leitor- 
explorador 28 fotos referentes ao contexto etnográfico da minha pesquisa de campo, que colocam em relevo as diversas cerimônias, rituais e relações por mim estabelecidas junto à comunidade Honmon Butsuryu-shu. Aqui reside a dupla potencialidade ${ }^{21}$ deste caderno visual, que consiste em dar a ver dois rituais distintos, mas que para mim foram oferecidos de maneira sobreposta, imbricados e de forma simultânea: o ritual e o contexto religioso $^{22}$, propriamente, que demonstra as diversas relações no âmbito sagrado e leigo da HBS; e o ritual que chamei de "fotográfico",23, que revela os elos estabelecidos no ato de fotografar, - em todos os seus âmbitos, desde a produção das imagens até as diversas formas como estas serão apropriadas ou esquecidas -, assim como a minha posição dentro da comunidade, primeiramente visto como um outsider e, gradativamente, legitimado como o "fotógrafo oficial” (Elias, 2018).

Assim, a intenção neste experimento é compartilhar uma interface com aquele que o vê e experimenta, para que possa estabelecer um debruçar, ou, em outros termos, um mergulho que indica uma relação não apenas visual com as imagens, mas também corpórea, sensorial e sinestésica, realizada a partir de múltiplos caminhos de exploração, inclusive distintos dos que eu estabeleci. No mapa existe, portanto, uma elaboração formal na composição de uma espécie de sudoku, um quebra-cabeça que convida o leitor-explorador a imergir, em primeira instância, em cada uma das 28 fotos. Depois de escavar os detalhes dessas imagens, uma a uma, ele precisará relacioná-las, em um esforço que inicialmente pode parecer meramente a racionalização dos processos e um exercício de lógica.

Porém, as imagens que compõem o mapa estão intimamente ligadas, sendo que o intuito ao construir esse jogo de sudoku também é o de estabelecer uma cartografia visual das relações encontradas em campo, que pretendo destacar com e pelas imagens, na qual o leitor precisará navegar sem um sentido fixo e rígido, quase à deriva. Aquele que visualiza é convidado a desconstruir o quebra-cabeça que montei, que possui vários níveis distintos, complexos e com lacunas, seguindo uma "lógica" que foi préestabelecida por mim. Mas, para fazer isso, ele precisará viajar com o corpo inteiro, deverá ver e tocar as imagens (no caso do mapa impresso), imaginando as possíveis relações acionadas não apenas por afinidades, mas também por distanciamentos. É

\footnotetext{
${ }^{21}$ Opto por utilizar o termo "potencialidade" ao invés de "função" porque, para mim, as fotografias são mais do que instrumentos ou ferramentas com uma utilidade meramente prática na pesquisa antropológica e no trabalho etnográfico.

${ }^{22}$ Capítulo 06 da tese, intitulado "O Odaimoku e os seus rituais".

${ }^{23}$ Capítulo 07 da tese, intitulado "A Fotografia como ritual antropológico".
} 
fundamental dizer que os mapas foram compostos exclusivamente por fotografias sem legendas ou explicações textuais, com o intuito de relacioná-las entre si, almejando estabelecer um pensamento com e por imagens.

Contudo, acrescentei um interlúdio na tese, logo após o mapa visual, com as descrições pormenorizadas dos meus caminhos de exploração imagética. Estabeleci os meus percursos para compor esse quebra-cabeça, com a intenção de guiar o leitorexplorador, minimamente, e mostrar o que desejo elencar com cada uma das imagens e, principalmente, com as conexões entre si. Dessa forma, saliento que essa é uma exploração possível e necessária analiticamente, mas que não restringe outras inúmeras formas de conectar tais fotografias e os seus componentes. Relembro, ainda, que as imagens fotográficas foram produzidas no encontro etnográfico, isto é, no contexto das relações intersubjetivas entre o pesquisador e os interlocutores no campo. "O que procuramos fazer é construir em imagens a experiência do encontro e dos motivos para esse encontro. E é a ética dessa relação que será vista como estética pelo espectador" (Barbosa, Cunha, Satiko e Novaes, 2016: 11).

A seguir, ofereço a exegese do primeiro percurso visual (imagens 20, 25 e 26) para exemplificar as relações que busquei elencar com o mapa:

O primeiro trecho apresentado é composto por cinco fotografias localizadas na parte central do mapa, sendo que a minha chave de leitura-exploração principal partirá da Imagem Sagrada Namumyouhourenguekyou. 


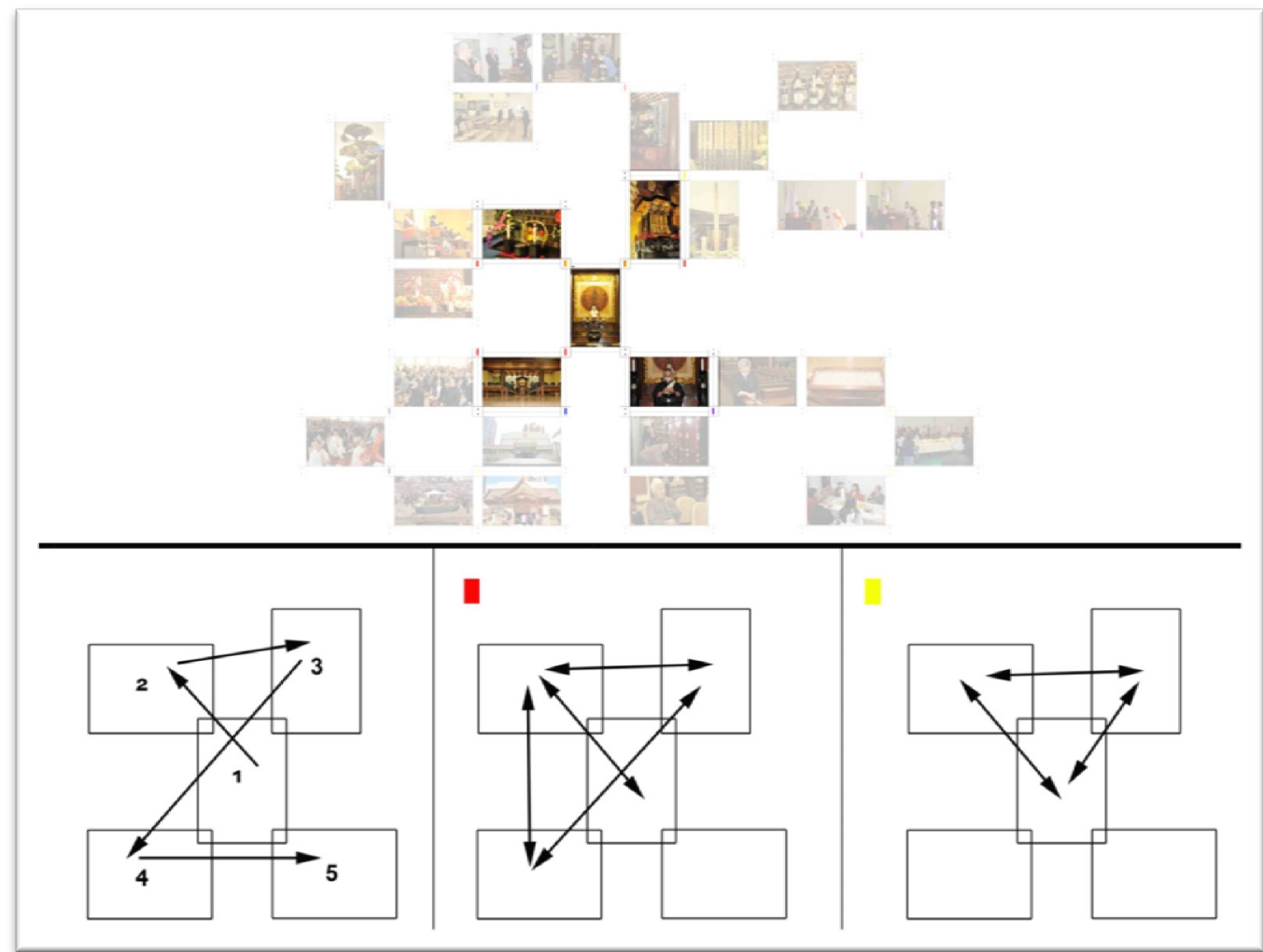

Imagem 25: Percurso visual 01 ampliado (montagem do autor).

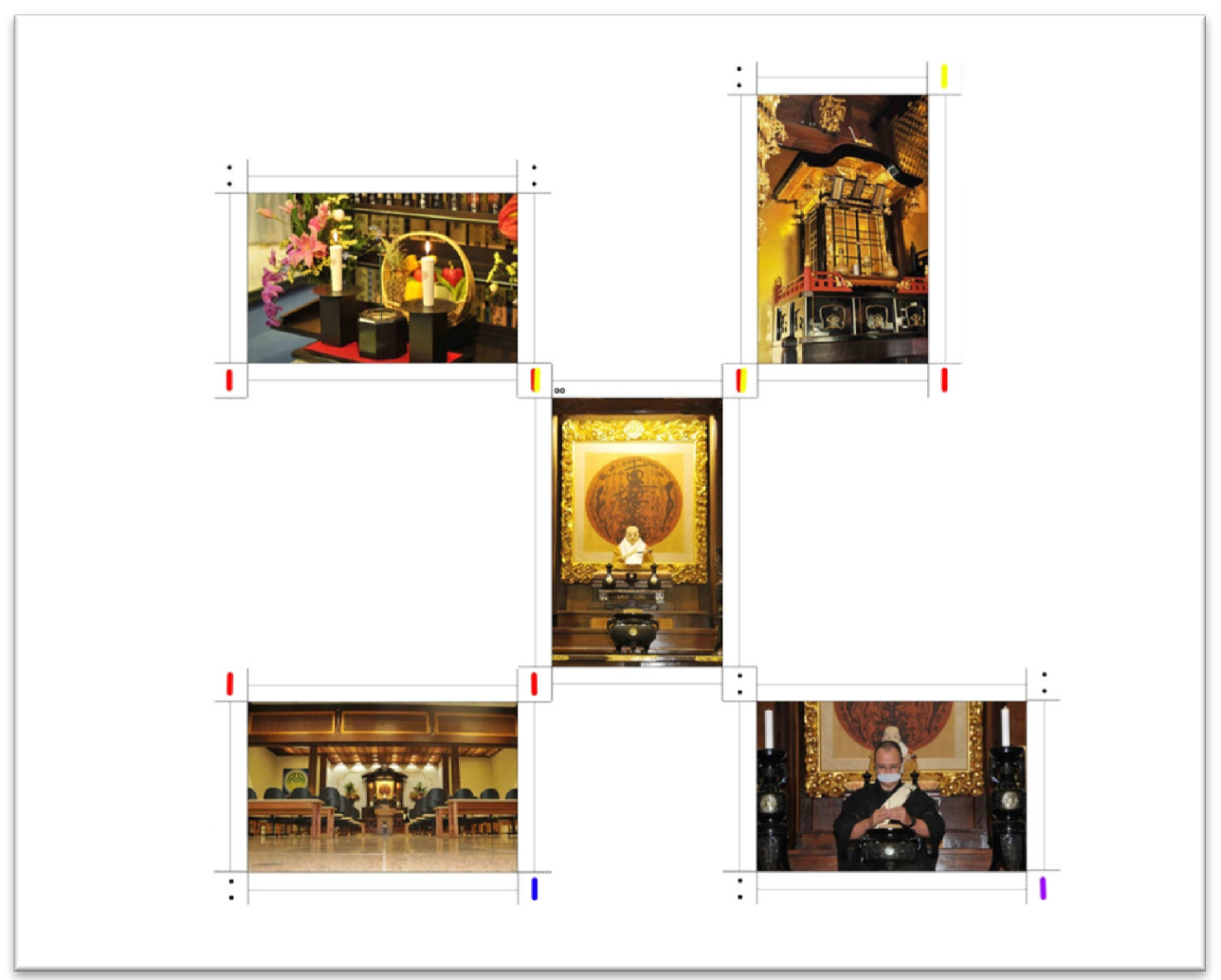

Imagem 26: Fotografias do percurso 01 ampliadas (montagem do autor). 
O que chama a minha atenção inicialmente na fotografia tomada como central é a iluminação em cores quentes (ou, em termos técnicos, com menores temperaturas de cor), na tonalidade amarela e vermelha, cuja qualidade de luz acentua a própria coloração da Imagem Sagrada, em dourado. Para obter essa fotografia utilizei uma lente considerada "mais clara", isto é, que possui uma amplitude de abertura de diafragma maior, o que possibilitou a captação de luminosidade ambiente sem a necessidade de utilização de um flash acoplado, cuja tonalidade é mais próxima da cor branca e azulada (cores frias, com maiores temperaturas de cor).

Na composição dessa fotografia, as opções técnicas/estéticas estão intimamente ligadas com as questões éticas, já que a imagem foi realizada na primeira visita de campo, que realizei em maio de 2011, na qual ainda me sentia (bastante) constrangido por incomodar os fiéis ao utilizar o flash ou lentes teleobjetivas (com maior zoom óptico). Além dessa escolha, fiz uso de uma objetiva fixa de $50 \mathrm{~mm}$ (chamada de "normal" por simular o campo de visão "normal" do ser humano), o que me obrigou a fotografar muito próximo ao Altar Sagrado, em um momento anterior à realização de um culto matinal, com poucas pessoas no Hondo ${ }^{24}$.

Três das quatro imagens conectadas a essa fotografia pelas extremidades também possuem as mesmas cores e variações tonais, embora existam diferenças formais importantes, como o enquadramento, por exemplo. Se na Imagem Sagrada a fotografia é confeccionada de forma frontal, centralizada, na posição vertical e levemente em contra-plongée (de baixo para cima ou, em uma tradução literal, "contramergulho"), a do canto superior esquerdo é tirada um pouco na diagonal, em plongée (de cima para baixo ou, em uma tradução literal, "mergulho").

$\mathrm{Na}$ verdade, como a Imagem Sagrada encontra-se sob um patamar um pouco mais elevado (sobre o Altar Sagrado), optei por retratá-la dessa maneira por uma opção estética, já que uma fotografia na vertical e em contra-plongée oferece ao elemento fotografado um aspecto grandioso (algo sagrado, no caso); e por uma posição ética, visto que existe uma restrição aos fiéis e observadores, que não devem subir no Altar, principalmente durante a realização do Culto Matinal. Além disso, o sentido da visualização dessa fotografia pelo leitor se dá verticalmente, ressaltando a Terra Pura de Buda (ornamento dourado e em forma de quadro/moldura) que contém o ensinamento sagrado, uma escritura em kanji que também deve ser lida/visualizada na vertical.

\footnotetext{
${ }^{24}$ Nave do templo budista, local onde se realizam as cerimônias principais.
} 
A imagem conectada pela parte superior esquerda também foi tirada em um Hondo, mas dessa vez no Templo Seifuji, na cidade de Osaka (Japão). Elenco, dessa forma, uma relação formal ${ }^{25}$ entre o círculo da Imagem Sagrada da fotografia central com a haste da pequena cesta de frutas da segunda foto, também em formato oval e cujos arranjos contendo as velas e os incensos remetem aos ornamentos da primeira imagem. Ao fundo, é possível ver alguns escritos em kanji e notar a presença dos símbolos butsumarus ${ }^{26}$ nas velas. Os kanjis também estão presentes na Imagem Sagrada da primeira imagem, sendo que o Butsumaru aparece acima dela, na parte nuclear, junto ao ornamento dourado que indica a Terra Pura de Buda ${ }^{27}$.

Já a imagem conectada no canto superior direito é um Altar dos Grandes Mestres da HBS, tirada em Osaka e tomada em contra-plongée. Devido às restrições referentes a subir até o local sagrado, realizei a fotografia em um plano inferior e lateralmente, pois no momento da confecção da imagem estava sendo celebrado um culto matinal e só pude fotografar a partir dessa perspectiva, já que os sacerdotes ocupavam o Gohouzen (altar sagrado).

A fotografia do Hondo da Catedral Nikkyoji, ligada pelo canto inferior esquerdo, foi realizada em contra-plongée frontal, com o intuito de acentuar, novamente, o aspecto grandioso desse local de realização das cerimônias da HBS. Essa foi uma das primeiras imagens que realizei em campo e foi confeccionada antes da realização de uma cerimônia e da chegada dos fiéis ao local. Para conseguir elaborar a fotografia do Hondo inteiro e ressaltar as suas cores, magnitude e riqueza de elementos rituais, tive que me afastar o máximo possível. Esse ato reafirma a opção de fotografar o local vazio, já que quando a nave do Templo está repleta de fiéis em grandes cerimônias, torna-se inviável retratar o Hondo completo.

Além dessas questões, é importante atentar para outro aspecto técnico importante. Utilizei uma objetiva $18 \mathrm{~mm}$, que permite um campo de visão expandido em relação ao olhar humano. Com essa escolha, portanto, pude incluir mais elementos na imagem, o que influencia esteticamente na fotografia, que fica mais arredondada nas extremidades ao gerar uma espécie de achatamento provocado pela menor distância

\footnotetext{
${ }^{25}$ Nas análises das fotografias, utilizo o termo "formal" para designar as formas presentes em cada imagem ou "dentro de" cada fotografia e o termo "composição" para designar as escolhas técnicas/estéticas do fotógrafo (ângulo, objetiva, diafragma, iluminação, etc.), embora esteja consciente de que tal diferenciação seja um tanto artificial.

${ }^{26}$ Símbolo da escola budista HBS.

${ }^{27}$ Também chamado de "Paraíso Budista".
} 
focal. Para confeccionar essa fotografia, tive ainda que colocar a câmera no chão e me deitar para olhar pelo visor da máquina e enquadrar o Hondo, outro motivo para compor a imagem em um momento anterior ao culto matinal e com o local vazio.

Já na fotografia unida à imagem central do mapa pela parte inferior direita, o fator que as conecta não é mais a semelhança, mas a distinção de tonalidades em relação às outras imagens mencionadas. Essa foto foi "tirada" com uma teleobjetiva $135 \mathrm{~mm}$ (que é própria para realizar closes) e com um flash dedicado, pois desejava ressaltar a colocação do incenso sob o Altar Sagrado pelo sacerdote Fabio Barbosa. Ao rever a imagem desse monge, que foi um importante interlocutor durante as pesquisas de campo no Brasil (tendo realizado até uma entrevista "oficial" com ele), recordo que em maio de 2011, quando fazia a minha primeira imersão na Catedral Nikkyoji, o acompanhava em uma ronda noturna para checar se todos os portões estavam fechados. $\mathrm{Na}$ ocasião, ele me contava sobre as dificuldades do exercício do sacerdócio, já que havia se licenciado de um cargo público para se tornar um monge da HBS. Também me dizia que, diferentemente da grande maioria dos clérigos da religião, ele residia em um apartamento com a sua esposa (na imagem, é possível notar a aliança de casamento no dedo anelar da mão esquerda, próximo do seu relógio) e um filho recém-nascido, na época. Segundo os seus relatos, esses fatores dificultavam a sua manutenção na carreira sacerdotal. Pouco tempo depois, tive a notícia de que ele havia voltado para o antigo emprego e deixado o monastério.

\section{REFERÊNCIAS}

BARBOSA, Andrea; CUNHA, Edgar Teodoro da; HIKIJI, Rose Satiko Gitirana; NOVAES, Sylvia Caiuby (orgs). A experiência da imagem na etnografia. São Paulo, Terceiro Nome, 2016.

BELTING, H. Antropología da imagem. Lisboa, KKYM + EAUM, 2014.

BENJAMIN, Walter. A obra de arte na época de suas técnicas de reprodução. São Paulo, Editora Abril, 1987 [1936].

Brasiliense, 2006.

Obras escolhidas. Magia e técnica, arte e política. São Paulo, 
. Experiência e pobreza. In. Obras escolhidas. Magia e técnica, arte e política. Ensaios sobre literatura e história da cultura. Prefácio de Jeanne Marie Gagnebin. São Paulo, Brasiliense, 1987. [1936].

BRUNO, Fabiana. Fotobiografia. Por uma Metodologia da Estética em Antropologia. 2009. 351f. Tese (Doutorado em Multimeios) - Instituto de Artes, Universidade Estadual de Campinas, Campinas, 2009.

CLIFFORD, James. A experiência etnográfica. Rio de Janeiro, Editora UFRJ, 2012 [2002].

DIDI-HUBERMAN, Georges. La imagen superviviente. Historia del arte y tiempo de los fantasmas segun Aby Warburg. Madrid, Editorial Abada, 2009 [2002].

. Imágenes pese a todo. Barcelona, Miracle Paidós, 2003.

. Quando as imagens tocam o real. Revista do Programa

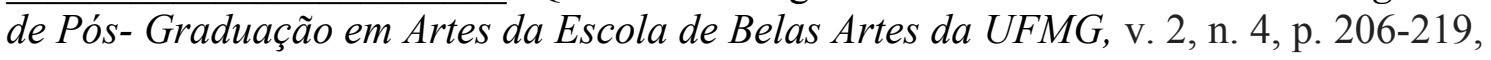
2012 .

história da arte. São Paulo, Editora 34, 2013.

Diante da imagem: questão colocada aos fins de uma

ELIAS, Alexsânder Nakaóka. Dupla imagem, duplo ritual: a Fotografia e o Sutra Lótus Primordial. Tese (Doutorado em Antropologia Social) - PPGAS-IFCH, Universidade Estadual de Campinas, Campinas, 2018.

GONÇALVES, Marco Antonio. Prefácio - Imagem e experiência. In. BARBOSA, Andrea; CUNHA, Edgar Teodoro da; HIKIJI, Rose Satiko Gitirana; NOVAES, Sylvia Caiuby (orgs). A experiência da imagem na etnografia. São Paulo, Terceiro Nome, 2016.

INGOLD, Tim. Trazendo as coisas de volta à vida: emaranhados criativos num mundo de materiais. Horizontes Antropológicos, n. 37, 2012, p. 25-44.

- Estar vivo: Ensaios sobre movimento, conhecimento e descrição. Petrópolis, Editora Vozes, 2015 [2011].

LATOUR, Bruno. Jamais fomos modernos: ensaio de antropologia simétrica. $2^{\text {a }}$ Ed. Rio de Janeiro, Editora 34, 2009 [1991].

LÉVI-STRAUSS, Claude. O cru e o cozido. Paris, Plon, 1964.

. Do mel às cinzas. Paris, Plon, 1967.

. A origem das maneiras à mesa. Paris, Plon, 1968.

. O homem nu. Paris, Plon, 1971.

. O Pensamento Selvagem. Campinas, Papirus, 2006. [1962] 
SAMAIN, Etienne (org.). Como pensam as imagens. Campinas, Editora da Unicamp, 2012.

WARBURG, Aby. Der Bilderatlas Mnemosyne (sob a direção de Martin Warnke e de Claudia Brink). Berlim, Akademie Verlag, 2000.

Macula, 2003. . Le Rituel du Serpent. Récit d'un voyage en pays pueblo. Paris, A renovação da Antiguidade pagã: Contribuições científicoculturais para a história do Renascimento europeu. Tradução de Markus Hediger. Rio de Janeiro, Editora Contraponto, 2013 [1932].

Recebido: $30 / 01 / 2020$

Aprovado: 15/07/2020 